\title{
IMPROVING THE QUALITY OF EDUCATION THROUGH THE PRINCIPAL'S STRATEGY TO DEVELOP TEACHER COMPETENCE
}

\author{
Ahmad Syukkur ${ }^{1}$, Fauzan ${ }^{2}$ \\ ${ }^{1}$ Universitas Islam Negeri Sunan Ampel Surabaya, Indonesia \\ ${ }^{2}$ Institut Pesantren Kh. Abdul Chalim Pacet Mojokerto, Indonesia \\ bangfauzan79@gmail.com
}

Accepted: 29-10-2021

\begin{abstract}
Principal's strategy is the art and knowledge gained by a principal in formulating, implementing, evaluating cross-functional decisions that facilitate the organization in achieving goals. Teachers are the key to the success of an educational institution. Good and bad behavior or teaching procedures for teachers will greatly affect the image of educational institutions. This study aims to examine and discuss in depth the principal's strategy in developing teacher competence at MA Tarbiyatul Islam Gending Probolinggo. This study uses a descriptive qualitative approach. Data collection techniques with interviews, observations and documentation. The results of the study indicate that: (1) The model that can be used to improve the competence of teachers in carrying out their duties is through In service education or In service training programs. (2) The strategic steps of the principal's leadership in developing teacher competence to improve the quality of education are the first formal strategy, namely the teacher is assigned by the institution to attend education and training, the second non-formal strategy, namely the teacher on his own desire and effort to train and develop himself related to work or position.
\end{abstract}

Keywords: Principal, Education Strategy, Teacher Competency Development

\section{INTRODUCTION}

Quality education requires strategic management of school principals and human resources. One of the most influential components in educational institutions is the teacher. To improve teacher performance, a school principal must have a strategy in improving teacher competence so that he can seek to improve education ${ }^{1}$. Principals must have the right strategy

1 Ari Kartiko and jaya Roza Azzukhrufi, "Pengaruh Budaya Organisasi Dan Kompensasi Terhadap Kinerja Pendidik Di Madrasah Aliyah Nahdlatul Ulama Mazro'atul Ulum Paciran," Nidhomul Haq: Jurnal Manajemen Pendidikan Islam 4, no. 2 (September 5, 2019): 207-26, https://doi.org/10.31538/ndh.v4i2.351; Een Nurjannah et al., "Teacher Performance Management in Improving Islamic Religious Education (IRE) Lesson Learning," Nidhomul Haq: Jurnal Manajemen Pendidikan Islam 6, no. 2 (August 1, 2021): 400-412, https://doi.org/10.31538/ndh.v6i2.1312. 
to empower educators to improve their competencies, and involve all educators in various activities that support school programs ${ }^{2}$.

One way to improve the quality of human resources is through quality education. The quality of education is achieved if the inputs, processes, graduates, teachers, facilities and infrastructure and costs meet the requirements ${ }^{3}$. From the point of view of quality management of education, the educational leadership reflected by the principal should include concern for efforts to improve the quality of education. In this connection, the quality of education can be interpreted as the ability of the educational unit, both technical and professional processing that will support the process of learning activities or other educational programs that are educational goals ${ }^{4}$.

Likewise, school principals who lead in educational institutions with Islamic educational backgrounds must also have a concern for efforts to improve the quality of Islamic education. In addition, they must be professional in managing educational institutions so that educational goals can be achieved ${ }^{5}$.

On the other hand, the leader is the ruler who is entitled to all decisions, but also carries a very heavy mandate. One of the duties of a leader is to bring about improvements in those he leads. This has been confirmed in QS. Ali Imran: 110 which means "You are the best people born for humans, enjoining the right and forbidding the evil, and believing in Allah. If the People of the Book had believed, it would have been better for them, among them there are believers, and most of them are ungodly."6

The verse above shows Muslims to call for goodness. Moreover, a leader who plays an important role as an exemplary figure, therefore the most important task of the leader is to call for the goodness of his members and the improvement of what he is doing. Quality education will increase human resources which in this era of globalization desperately need quality human beings for nation building. Therefore, improving the quality of education is very important to create quality human resources ${ }^{7}$.

2 Mohamad Iwan Fitriani and Mohammad Viktor Farid Hakim, "Principal Leadership Patterns in Collaborating With School Committee," Nidhomul Haq : Jurnal Manajemen Pendidikan Islam 6, no. 1 (May 21, 2021): 194-205, https://doi.org/10.31538/ndh.v6i1.1384; Nova Syafira Ariyanti, Ahmad Supriyanto, and Agus Timan, "Kontribusi Kepala Sekolah Berdasarkan Ketidaksesuain Kualifikasi Guru Untuk Meningkatkan Kualitas Sekolah," Nidhomul Haq: Jurnal Manajemen Pendidikan Islam 4, no. 2 (September 5, 2019): 157-68, https://doi.org/10.31538/ndh.v4i2.314.

3 Sumaia A. Al-Kohlani, Improving Educational Gender Equality in Religious Societies: Human Rights and Modernization Pre-Arab Spring (Palgrave Macmillan, 2018), https://doi.org/10.1007/978-3-319-70536-1; Suwadi Suwadi, "Educational Leadership Based on Social Capital for Improving Quality of Private Secondary School," Jurnal Pendidikan Islam 6, no. 2 (December 27, 2017): 449, https://doi.org/10.14421/jpi.2017.62.449-478.

4 Abu Darim, "Manajemen Perilaku Organisasi Dalam Mewujudkan Sumber Daya Manusia Yang Kompeten," Munaddhomah: Jurnal Manajemen Pendidikan Islam 1, no. 1 (March 25, 2020): 22-40, https://doi.org/10.31538/munaddhomah.v1i1.29.

${ }^{5}$ Melanie C. Brooks and Agus Mutohar, "Islamic School Leadership: A Conceptual Framework," Journal of Educational Administration and History 50, no. 2 (April 3, 2018): 54-68, https://doi.org/10.1080/00220620.2018.1426558; Miriam Ezzani and Melanie Brooks, "Culturally Relevant Leadership: Advancing Critical Consciousness in American Muslim Students," Educational Administration Quarterly 55, no. 5 (December 1, 2019): 781-811, https://doi.org/10.1177/0013161X18821358.

${ }^{6}$ Departemen Agama RI, Al-Quran Dan Terjemahnya (Jakarta: Departemen Agama RI, 2010).

7 Sedya Santosa and Aulia Diana Devi, "The Problematics Online Lectures on Human Resource Management Courses (HRM) at The Islamic College Level," Naz̧hruna: Jurnal Pendidikan Islam 4, no. 2 (June 20, 2021): 261-71, https://doi.org/10.31538/nzh.v4i2.1452; Barnoto Barnoto, "Merespon Perubahan Dalam 
The quality of education is still a major problem in the field of education in Indonesia, both at the higher education level as well as primary and secondary education. The quality of education in Indonesia is decreasing, due to a significant increase in the population, but is not supported by current conditions. One of the causes is: (1) learning facilities, which are not evenly distributed between urban and rural areas, which are still not evenly distributed, (2) very strict government regulations make education depressed, (3) teaching and learning activities are still fixated on one book and books often change each other. , (4) Monotonous learning model that can bore students (5) Cheating culture, cheating culture is growing rapidly among students, especially during exams, (6) Student and teacher discipline levels are still low, and (8) Poverty still affects dropouts school because it helps the economy of parents to earn money ${ }^{8}$.

MA Tarbiyatul Islam describes one of the private madrasah in Probolinggo which is located in Gending District. MA Tarbiyatul Islam is located in Sumberkerang Village, the location is strategic and easy to reach by transportation. The surrounding community feels proud when their children attend MA Tarbiyatul Islam, because those who are accepted to study at MA Tarbiyatul Islam are not just any students, but must be students who are able to produce people who have noble character, are intelligent, creative, skilled and broad-minded and can follow developments. science and technology. Therefore, MA Tarbiyatul Islam has gained the trust of the surrounding community that the madrasa is a religious madrasa and has graduated with human personality.

MA Tarbiyatul Islam was founded by the late KH. Mohdlori Kholis. The first time KH. Mohdlori Kholis founded the Tarbiyatul Islamic Boarding School as the forerunner to the establishment of MA Tarbiyatul Islam to accommodate students to be in the cottage environment as an addition or deepen their religious knowledge. The Islamic boarding school was founded in 2014. After KH. Mohdlori Kholis, the management of the Tarbiyatul Islamic boarding school was continued by his son Muhammad Imron Firdaus who is also the caretaker of the Tarbiyatul Islam boarding school. The beginning of PP. Tarbiyatul Islam is a Salafiyah Islamic Boarding School whose students still number eleven students who still inhabit a simple nanny's house as a boarding house. For their patience and persistence, $\mathrm{H}$. Mohdlori Kholis and Nyai Hj. Nurmillah founded the Tarbiyatul Islam Education Foundation (YPTI). The purpose of establishing the Tarbiyatul Islam Education Foundation (YPTI) is to ease the burden on the community to obtain formal education in accordance with today's times. The Tarbiyatul Islam Education Foundation has a vision of providing salafy Islamic education with modern management. Meanwhile, the mission of the Tarbiyatul Islam Education Foundation is to develop the Islamic values of Ahlussunah wal Jamaah through formal education, namely Madrasah Aliyah (MA), the educational institution that the researcher chose as a place of research. In realizing the vision of MA Tarbiyatul Islam, of course, there is a role for the Head of Madrasa and Professional Teacher Resources as supporters who are able to provide complete and comprehensive education and can improve the quality of education at MA Tarbiyatul Islam.

Pemenuhan Kebutuhan Sumber Daya Manusia Di SMP Negeri 1 Pacet," Munaddhomah: Jurnal Manajemen Pendidikan Islam 1, no. 1 (2020): 1-10, https://doi.org/10.31538/munaddhomah.v1i1.27.

${ }^{8}$ Raymond Godwin, "Rendahnya Kualitas Pendidikan Di Indonesia," Psychology (blog), accessed October 21, 2021, https://psychology.binus.ac.id/2017/02/17/rendahnya-kualitas-pendidikan-di-indonesia/. 


\section{Method}

This article used qualitative research with a case study approach. The research location is MA Tarbiyatul Islam Gending Probolinggo which is located on Jl. Banyu Biru, Gending District, Probolinggo Regency, is precisely under the auspices of the Tarbiyatul Islam Education Foundation. data collection techniques by observation, interviews and documentation. The data analysis techniques carried out according to Miles are: 1) reduction, 2) data presentation, 3) drawing conclusions. Informants from this study were principals, vice principals, teachers, staff and school committees.

\section{Result and Discussion}

\section{Teacher Competency Development Model at MA Tarbiyatul Islam}

The teacher competency development model at MA Tarbiyatul Islam uses the In Service Training model, which is a coaching program for teachers in the form of education and training. Teachers attend various trainings and seminars related to education to improve their competence.

In Service Training Objectives, In general, the objectives of in service training activities are as follows: 1) Increase work productivity, 2) Increase efficiency, 3) Reduce the occurrence of various damages, 4) Reduce the rate of accidents at work, 5) Improve better service , 6) Improve employee morale, 7) Provide opportunities for career advancement, 8) Improve manager's decision-making ability, 9) Improve one's leadership better, 10) Increase compensation.

\section{In-service Training Activities}

The form of implementation of in-service training activities at MA Tarbiyatul Islam is divided into two ways, namely: 1) formal development, namely teachers are assigned by the institution to attend education and training. 2) non-formal development, namely teachers on their own desires and efforts to train and develop themselves in relation to their work or position.

The steps in implementing development training at MA Tarbiyatul Islam are as follows: 1) Determining training needs, 2) Developing a training design, 3) Developing program content, 4) Selecting Training Media and Learning Principles, 5) Training implementation, 6) Evaluating training.

Principals must have the right strategy to empower educators to improve their competencies, and involve all educators in various activities that support school programs ${ }^{9}$. Experts argue that education and training will provide assistance in the future by developing a mindset and acting, skilled in knowledge and having the right attitude and understanding for the implementation of the work ${ }^{10}$. As explained by Julia, an In Service Training program was

\footnotetext{
${ }_{9}^{9}$ Nilda Nilda, Hifza Hifza, and Ubabuddin Ubabuddin, "Peran Kepala Sekolah Sebagai Supervisor Dalam Meningkatkan Kinerja Guru Pendidikan Agama Islam Sekolah Dasar," Attadrib: Jurnal Pendidikan Guru Madrasah Ibtidaiyah 3, no. 1 (April 25, 2020): 12-18, https://jurnal.staidagresik.ac.id/index.php/attadrib/article/view/160.

10 Enco Mulyasa, Menjadi kepala sekolah profesional: dalam konteks menyukseskan MBS dan KBK (Remaja Rosdakarya, 2006).
} 
held to assist teachers in improving four competencies, namely personality competence, social competence, pedagogic competence and professional competence ${ }^{11}$.

The implementation of this in-service training program also provides benefits for teachers and for the MA Tarbiyatul Islam institution. The benefits for teachers are increasing the teacher's ability to handle various activities at hand, providing encouragement for teachers to deal with stress, frustration and conflict in the future can increase self-confidence, add information about various programs that can be utilized by employees in the form of increasing technical knowledge. as well as intellectually and minimize panic facing new tasks in the future.

The formal application of the program is that teachers are delegated by educational institutions to take part in education or training, whether carried out by the school itself or by educational or training institutions. This can be done through seminars, workshops, and others. Meanwhile, non-formal development is the teacher's own desire and effort to train and develop himself by studying literature books related to his job or position.

Principals in fostering the professional career of teachers and education staff must have a strategy so that their leadership tasks run well. Mr. Kamaluddin, M.Pd. as the Head of the School seeks how educators in MA Tarbiyatul Islam can develop their competencies, the strategies implemented are as follows:

\section{Education and Training \\ in House Training (IHT)}

IHT is training that is implemented internally in teacher working groups, schools or other places set to conduct training. The coaching strategy through IHT is carried out based on the idea that some abilities in improving teacher competence and careers do not have to be done externally, but can be done by teachers who have competencies that other teachers do not have, with this strategy it is expected to save more time and costs ${ }^{12}$.

Internal coaching by the school. This internal coaching is carried out by school principals and teachers who have the authority to foster, through official meetings, rotation of teaching assignments, provision of additional internal tasks, discussions with colleagues and the like.

\section{MGMP $^{13}$ (Association of Subject Teachers)}

MGMP is implemented to obtain useful products for learning, competency improvement and career development. Workshops can be carried out, for example in the preparation of learning tools such as writing lesson plans, Prota, Promis, Assessment and so on.

\section{Additional Activities}

Discussion on education.: This discussion is carried out with a periodic model with the theme of discussion according to the problems experienced at school. Through this periodic

${ }^{11}$ Julia Bluestone et al., "Effective In-Service Training Design and Delivery: Evidence from an Integrative Literature Review," Human Resources for Health 11, no. 1 (October 1, 2013): 51, https://doi.org/10.1186/14784491-11-51.

12 Suhandi Astuti, Slameto Slameto, and Yari Dwikurnaningsih, "Peningkatan Kemampuan Guru Sekolah Dasar Dalam Penyusunan Instrumen Ranah Sikap Melalui in House Training," Kelola: Jurnal Manajemen Pendidikan 4, no. 1 (June 29, 2017): 37-47, https://doi.org/10.24246/j.jk.2017.v4.i1.p37-47.

${ }^{13}$ Indonesian (Musyawarah Guru Mata Pelajaran) 
discussion, it is hoped that the teacher council will find solutions that are experienced in relation to teaching and learning activities in schools or problems of increasing competence and developing their careers.

Seminars: Delegation of teachers in seminars and development of scientific publications can also create a model of continuous development for teacher professional improvement. This activity provides an opportunity for teachers to correlate scientifically with colleagues related to actual matters in an effort to improve the quality of education. Principal Strategic Steps in Teacher Competency Development at MA Tarbiyatul Islam.

\section{Formal Strategy \\ Delegating teacher training}

In terms of Teacher Training and Education (PPTG) ${ }^{14}$ activities as well as educational staff. This activity aims to keep teachers up-to-date in following science and technology and the progress of the times, especially changes in education and learning at a macro level ${ }^{15}$.

MA Tarbiyatul Islam, often involves teachers in training, seminars, and training to improve achievement and knowledge about education. Implementation of wotkshop to develop the ability of teachers in realizing teaching and learning methods. The implementation is carried out by inviting experts as resource persons. The material is adapted to the needs of the educational function in schools, such as management, leadership, teaching and learning activities, administration, and others.

Therefore, the flexibility of training in almost all prospects, education and training is often chosen as a resolution to overcome the problem of teacher quality at MA Tarbiyatul Islam. The review that needs to be revealed so that the training can be intense to solve the problem of teacher quality is that the implementation of the training should be committed to the goal.

\section{Include Teachers in Seminars}

The seminar is a study that focuses on a specific theme, in which those present are actively involved. Seminars are sometimes held by means of dialogue with the seminar moderator or presentation of research results in a more formal format. The seminar system has the idea of bringing students closer to the topic being discussed. Seminar is a discussion of scientific problems even though the topics discussed are everyday problems. In discussing problems, the goal is to find something to solve the problem ${ }^{16}$. Therefore, a seminar always ends with conclusions or decisions that are the result of a common opinion. The discussion of the seminar is based on papers or working papers that have been prepared previously by several speakers in accordance with the subject matter requested by an organizer which will be discussed theoretically ${ }^{17}$.

The seminar at MA Tarbiyatul Islam was carried out by two people who always gave motivation to other teachers, namely Mr. Kamaluddin, M.Pd. as the Head of the School with a person who can be trusted in this case was handed over to Mrs. Nuri Wilda as the Deputy

${ }^{14}$ Indonesian (Pendidikan dan Pelatihan Tenaga Guru)

15 Prof Dr Sudarwan Danim, Pengembangan Profesi Guru (Prenada Media, 2012).

16 Umniyatul Azizah et al., "Pemahaman Guru Terhadap Standar Isi Sekolah Lanjutan Tingkat Pertama Kota Bandung," Tafkir: Interdisciplinary Journal of Islamic Education 2, no. 2 (August 3, 2021): 191-206, https://pasca.jurnalikhac.ac.id/index.php/tijie/article/view/25.

${ }^{17}$ Sulistyorini, Evaluasi Pendidikan Dalam Meningkatkan Mutu Pendidikan (Yogjakarta: Teras, 2009). 
Head of Curriculum, she together encouraged other teachers. In developing teacher competencies, the Principal motivates them to be creative and innovative by implementing several strategies for teachers and their staff who are within the MA Tarbiyatul Islam.

\section{Involving the MGMP program}

MA Tarbiyatul Islam teachers are required to take part in the Subject Teacher Consultation as well as the KKG, which is a teacher organization that was initiated as a communication forum that leads to solving problems faced by teachers in carrying out their duties in the field. This is an idea from the Principal so that teaching teachers have preparation and can master the material, therefore the MA Tarbiyatul Islam teacher is very grateful to the Head of Madrasah.

In this case, according to Wina Sanjaya, there are several objectives to hold this MGMP, namely: 1) To motivate teachers to improve their abilities and skills in planning, implementing and evaluating learning programs in order to increase self-confidence as professional teachers; 2) To improve the ability and proficiency of teachers in carrying out learning so as to support efforts to improve and equalize the quality of education; 3) To discuss the problems faced and experienced by teachers in carrying out their daily tasks and find alternative solutions according to the characteristics of each teacher's subject matter, school conditions, and the environment; 4) To help teachers obtain educative technical information related to science and technology activities, curriculum activities, methodologies and testing systems in accordance with the subjects concerned; 5) To share information and experiences with each other from the results of workshops, symposia, seminars, education and training, classroom action research, references, and other professional activities that are discussed together ${ }^{18}$.

\section{Supervise}

Principals in carrying out their duties as supervisors, principals must be experts in carrying out various supervision and control to foster the performance of educators and education staff. This inspection is a control so that educational activities are aimed at the goals set. In addition to carrying out inspections of principals and carrying out assistance and guidance to teachers or to education staff when experiencing difficulties ${ }^{19}$.

The principal after supervising the subject teachers. According to him, there are two follow-up options in the implementation of supervision at MA Tarbiyatul Islam. First, the principal conveys personally and the second conveys in groups, especially learning evaluations. Then the Principal evaluates the results of the supervision forum.

Educational supervision is assistance that is intentionally given by supervisors to teachers to improve and develop teaching and learning situations including stimulating,

18 Sanjaya Wina, Strategi Pembelajaran: Berorientasi Standar Psoses Pendidikan, 11th ed. (Jakarta: Kencana Prenada Media Group, 2006).

19 Saiful Asyari, "Supervisi Kepala Madrasah Berbasis Penilaian Kinerja Sebagai Upaya Peningkatan Profesionalitas Guru," JIEMAN: Journal of Islamic Educational Management 1, no. 2 (June 24, 2020): 149-63, https://doi.org/10.35719/jieman.v1i2.14; Amal Al-Kiyumi and Waheed Hammad, "Preparing Instructional Supervisors for Educational Change: Empirical Evidence From the Sultanate of Oman," SAGE Open 10, no. 2 (April 1, 2020): 2158244020935905, https://doi.org/10.1177/2158244020935905. 
coordinating and guiding the continuous growth of teachers more effectively in achieving educational goals ${ }^{20}$.

\section{Peer Teaching}

The Peer Teaching Program is one of the teacher quality development programs in teaching and learning activities. This activity is a teaching simulation where there is one teacher who teaches and another teacher becomes the student as well as the Head of Madrasah as his student. Through this activity, teachers can provide input for improvement and find out their weaknesses in teaching other teachers.

Peer teaching is a learning method with a cooperative approach where there are students who act as teachers (usually students who are smarter than other students) and other students act as learners, either at the same age or the teacher is older than the learner, to helps learning within the same grade level, to develop better abilities to listen, concentrate, and understand what is being learned in a meaningful way ${ }^{21}$.

\section{Non-Formal Strategy \\ Application of Discipline}

To improve the competence of qualified teachers and graduates, the principal as a leader has the obligation to instill discipline in his subordinates. As a leader, he must be a role model for his subordinates, like what Mr. Kamal as the principal did, he always arrived earlier than his subordinates, at $6.40 \mathrm{WIB}$ he was already at MA Tarbiyatul Islam and when he came home late, this is the result of our observations as researcher.

Mr. Kamal as the leader, requires teachers to give permission letters along with the reasons and give assignments to students if there are obstacles to attending, this is an administrative order for teachers so that teachers don't just attend. This personality competency is the basic capital for school principals to be able to carry out their duties professionally. This personality competency is the main key because a school principal is a figure who is an example as well as an example in his school ${ }^{22}$.

\section{Giving motivation}

As leaders who are responsible for achieving goals through other people or employees, they are expected to have the ability to motivate employees. to work harder ${ }^{23}$. Principals and as motivators have the right strategy to motivate teachers in carrying out their various tasks and functions. That motivation can be developed through.

Provision of Adequate Facilities and Infrastructure: Supporting and adequate facilities and infrastructure is the desire of all schools, including the desire of the Principal to try to improve existing facilities, so that teachers feel comfortable in teaching and learning activities.

${ }^{20}$ Sri Budiman and Suparjo Suparjo, "Manajemen Strategik Pendidikan Islam," JISIP Jurnal Ilmu Sosial Dan Pendidikan) 5, no. 3 (July 16, 2021), https://doi.org/10.36312/jisip.v5i3.2197.

${ }^{21}$ Syaiful Bahri Djamarah, Pola komunikasi orang tua dan anak dalam keluarga (sebuah perspektifpendidikan Islam) (Jakarta: Rineka Cipta, 2004).

22 Sadaf Umer Chhapra et al., "Analysis of Students Perception about Teachers' Personality in the Academic Achievement," TARBIYA: Journal of Education in Muslim Society 5, no. 1 (June 28, 2018): 101-15, https://doi.org/10.15408/tjems.v5i1.7098.

23 Zainal Arifin, "The Authority of Spiritual Leadership at Pesantren Temboro Based on Jamaah Tabligh Ideology," Jurnal Pendidikan Islam 6, no. 2 (December 27, 2017): 265-92, https://doi.org/10.14421/jpi.2017.62.265-292. 
Facilities and infrastructure is also a supporter in the teaching and learning process. At MA Tarbiyatul Islam, one of the infrastructure facilities accommodated by the Principal is the provision of LCDs in the classrooms, although it has not been fully realized, currently it is still in the process of fulfilling LCDs in all classes. In addition, there is also CCTV in the classrooms to monitor the teaching and learning process from the principal's office.

Discipline: Teacher competence needs to be improved, for that the Principal. trying to cultivate discipline in all his staff. Through this discipline, it is hoped that goals can be achieved effectively and efficiently, and can produce quality graduates.

Each education staff has different characteristics from one another, so they require special attention and service from their leaders so that they can take advantage of the time to improve their competencies. Mr. Kamal motivates all educators and other teaching staff to continue to be creative in improving the quality of learning.

Improving teacher competence requires motivation and support from various parties, as well as motivation from school principals. The principal always encourages or motivates all teachers to be more creative and innovative in the learning process in the classroom. With the motivation of the principal, the teacher becomes enthusiastic in carrying out his duties. Encouragement or motivation does not only come from the principal but all teachers also motivate themselves to improve their professional competence ${ }^{24}$.

\section{Human Resources Development}

Human resource development is very important for the educational process, therefore the principal conducts coaching when education and education personnel have been accepted to take part in all coaching in improving quality. There is an increase in skills and training, workshops and supervision from the principal. Then there is also assistance when there are teachers and employees experiencing difficulties in making such as Learning Plans ${ }^{25}$.

Giving directions every time the weekly meeting at MA Tarbiyatul Islam is often carried out. In addition, teachers and employees here have facilities for learning related to Islamic education through the development of teachers and employees. Every teacher and employee also has a target that must be achieved, so it's not just students who get selfimprovement targets. For example in terms of worship every day. One of the purposes of this coaching is to remind them that it is important to improve themselves.

Human Resources in an organization are not only as implementers of work programs, but also play a role in realizing organizational goals. Therefore, it is necessary to pay attention to the development of human resources so that they are of higher quality ${ }^{26}$.

In developing the quality of teachers at MA Tarbiyatul Islam, the principal employs and develops quality through planned activities. The principle of the principal is to want to

${ }^{24}$ Yakobus Bwarnirun and Budi Santoso, "Pengaruh Motivasi Guru Terhadap Hasil Belajar Matematika Materi Pecahan Pada Siswa Kelas IV Ssekolah Dasar Inpres 109 Perumnas Kota Sorong," Attadrib: Jurnal Pendidikan Guru Madrasah Ibtidaiyah 4, no. 1 (April 21, 2021): 13-24, https://jurnal.staidagresik.ac.id/index.php/attadrib/article/view/115.

25 Abderrahman Hassi, "Islamic Perspectives on Training and Professional Development," ed. Wafa El Garah et al., Journal of Management Development 31, no. 10 (January 1, 2012): 1035-45, https://doi.org/10.1108/02621711211281816.

26 Syamsul Bahri and Novira Arafah, "Analisis Manajemen SDM Dalam Mengembangkan Strategi Pembelajaran Di Era New Normal,” Tafkir: Interdisciplinary Journal of Islamic Education 1, no. 1 (2020): 20-40, https://doi.org/10.31538/tijie.v1i1.2. 
make the teacher a leader. Each activity and determine the vision, mission and goals that involve all teachers and staff. So the one who is responsible here is not only the principal but all of them. In addition, in every activity all teachers will be involved and each teacher will get a share to lead the activity.

\section{CONCLUSSION}

The teacher competency development model in improving the quality of education at MA Tarbiyatul Islam Gending Probolinggo is an In service training program, namely a coaching program for teachers in the form of education and training. Principals use this model because it can motivate teachers to continuously improve their competence in terms of knowledge, skills, or attitudes of teachers and education staff. The strategic steps of the Principal's leadership in developing teacher competence to improve the quality of education at MA Tarbiyatul Islam Gending Probolinggo are divided into two strategic activities, the first is a formal strategy, namely teachers are assigned by the institution to participate in education and training, both those carried out by the school institution itself and by educational/training institutions, due to current or future job demands such as: participation in courses and training, seminars, and MGMP. The second, non-formal strategies, namely the application of discipline, providing motivation, developing human resources and employing teachers.

\section{REFERENCES}

Al-Kiyumi, Amal, and Waheed Hammad. "Preparing Instructional Supervisors for Educational Change: Empirical Evidence From the Sultanate of Oman." SAGE Open 10, no. 2 (April 1, 2020): 2158244020935905. https://doi.org/10.1177/2158244020935905.

Al-Kohlani, Sumaia A. Improving Educational Gender Equality in Religious Societies: Human Rights and Modernization Pre-Arab Spring. Palgrave Macmillan, 2018. https://doi.org/10.1007/978-3-319-70536-1.

Arifin, Zainal. "The Authority of Spiritual Leadership at Pesantren Temboro Based on Jamaah Tabligh Ideology." Jurnal Pendidikan Islam 6, no. 2 (December 27, 2017): 265-92. https://doi.org/10.14421/ipi.2017.62.265-292.

Ariyanti, Nova Syafira, Ahmad Supriyanto, and Agus Timan. "Kontribusi Kepala Sekolah Berdasarkan Ketidaksesuain Kualifikasi Guru Untuk Meningkatkan Kualitas Sekolah.” Nidhomul Haq : Jurnal Manajemen Pendidikan Islam 4, no. 2 (September 5, 2019): 157-68. https://doi.org/10.31538/ndh.v4i2.314.

Astuti, Suhandi, Slameto Slameto, and Yari Dwikurnaningsih. "Peningkatan Kemampuan Guru Sekolah Dasar Dalam Penyusunan Instrumen Ranah Sikap Melalui in House Training." Kelola: Jurnal Manajemen Pendidikan 4, no. 1 (June 29, 2017): 37-47. https://doi.org/10.24246/j.jk.2017.v4.i1.p37-47.

Asyari, Saiful. "Supervisi Kepala Madrasah Berbasis Penilaian Kinerja Sebagai Upaya Peningkatan Profesionalitas Guru." JIEMAN: Journal of Islamic Educational Management 1, no. 2 (June 24, 2020): 149-63. https://doi.org/10.35719/jieman.v1i2.14.

Azizah, Umniyatul, Chairul Rahman, Ida Farida, and Nina Nurmilasari. "Pemahaman Guru Terhadap Standar Isi Sekolah Lanjutan Tingkat Pertama Kota Bandung." Tafkir: 
Interdisciplinary Journal of Islamic Education 2, no. 2 (August 3, 2021): 191-206. https://pasca.jurnalikhac.ac.id/index.php/tijie/article/view/25.

Bahri, Syamsul, and Novira Arafah. "Analisis Manajemen SDM Dalam Mengembangkan Strategi Pembelajaran Di Era New Normal." Tafkir: Interdisciplinary Journal of Islamic Education 1, no. 1 (2020): 20-40. https://doi.org/10.31538/tijie.v1i1.2.

Barnoto, Barnoto. "Merespon Perubahan Dalam Pemenuhan Kebutuhan Sumber Daya Manusia Di SMP Negeri 1 Pacet." Munaddhomah: Jurnal Manajemen Pendidikan Islam 1, no. 1 (2020): 1-10. https://doi.org/10.31538/munaddhomah.v1i1.27.

Bluestone, Julia, Peter Johnson, Judith Fullerton, Catherine Carr, Jessica Alderman, and James BonTempo. "Effective In-Service Training Design and Delivery: Evidence from an Integrative Literature Review." Human Resources for Health 11, no. 1 (October 1, 2013): 51. https://doi.org/10.1186/1478-4491-11-51.

Brooks, Melanie C., and Agus Mutohar. "Islamic School Leadership: A Conceptual Framework." Journal of Educational Administration and History 50, no. 2 (April 3, 2018): 54-68. https://doi.org/10.1080/00220620.2018.1426558.

Budiman, Sri, and Suparjo Suparjo. "Manajemen Strategik Pendidikan Islam." JISIP Jurnal Ilmu Sosial Dan Pendidikan) 5, no. 3 (July 16, 2021). https://doi.org/10.36312/jisip.v5i3.2197.

Bwarnirun, Yakobus, and Budi Santoso. "Pengaruh Motivasi Guru Terhadap Hasil Belajar Matematika Materi Pecahan Pada Siswa Kelas IV Ssekolah Dasar Inpres 109 Perumnas Kota Sorong." Attadrib: Jurnal Pendidikan Guru Madrasab Ibtidaiyah 4, no. 1 (April 21, 2021): 13-24. https://jurnal.staidagresik.ac.id/index.php/attadrib/article/view/115.

Chhapra, Sadaf Umer, Saba Naz, Mehmood Usmani, and Adil Mohiuddin. "Analysis of Students Perception about Teachers' Personality in the Academic Achievement." TARBIYA: Journal of Education in Muslim Society 5, no. 1 (June 28, 2018): 101-15. https://doi.org/10.15408/tjems.v5i1.7098.

Danim, Prof Dr Sudarwan. Pengembangan Profesi Guru. Prenada Media, 2012.

Darim, Abu. "Manajemen Perilaku Organisasi Dalam Mewujudkan Sumber Daya Manusia Yang Kompeten." Munaddhomah: Jurnal Manajemen Pendidikan Islam 1, no. 1 (March 25, 2020): 22-40. https://doi.org/10.31538/munaddhomah.v1i1.29.

Departemen Agama RI. Al-Quran Dan Terjemahnya. Jakarta: Departemen Agama RI, 2010.

Djamarah, Syaiful Bahri. Pola komunikasi orang tua dan anak dalam keluarga (sebuah perspektif pendidikan Islam). Jakarta: Rineka Cipta, 2004.

Ezzani, Miriam, and Melanie Brooks. "Culturally Relevant Leadership: Advancing Critical Consciousness in American Muslim Students." Educational Administration Quarterly 55, no. 5 (December 1, 2019): 781-811. https://doi.org/10.1177/0013161X18821358.

Fitriani, Mohamad Iwan, and Mohammad Viktor Farid Hakim. "Principal Leadership Patterns in Collaborating With School Committee.” Nidhomul Haq: Jurnal Manajemen Pendidikan Islam 6, no. 1 (May 21, 2021): 194-205. https://doi.org/10.31538/ndh.v6i1.1384.

Godwin, Raymond. "Rendahnya Kualitas Pendidikan Di Indonesia." Psychology (blog). Accessed October 21, 2021. https://psychology.binus.ac.id/2017/02/17/rendahnyakualitas-pendidikan-di-indonesia/. 
Hassi, Abderrahman. "Islamic Perspectives on Training and Professional Development." Edited by Wafa El Garah, Rafik I. Beekun, André Habisch, Gilbert Lenssen, and Cristian Loza Adaui. Journal of Management Development 31, no. 10 (January 1, 2012): 1035-45. https://doi.org/10.1108/02621711211281816.

Kartiko, Ari, and jaya Roza Azzukhrufi. "Pengaruh Budaya Organisasi Dan Kompensasi Terhadap Kinerja Pendidik Di Madrasah Aliyah Nahdlatul Ulama Mazro'atul Ulum Paciran." Nidhomul Haq: Jurnal Manajemen Pendidikan Islam 4, no. 2 (September 5, 2019): 207-26. https://doi.org/10.31538/ndh.v4i2.351.

Mulyasa, Enco. Menjadi kepala sekolah profesional: dalam konteks menyukseskan MBS dan KBK. Remaja Rosdakarya, 2006.

Nilda, Nilda, Hifza Hifza, and Ubabuddin Ubabuddin. "Peran Kepala Sekolah Sebagai Supervisor Dalam Meningkatkan Kinerja Guru Pendidikan Agama Islam Sekolah Dasar." Attadrib: Jurnal Pendidikan Guru Madrasah Ibtidaiyah 3, no. 1 (April 25, 2020): 12-18. https://jurnal.staidagresik.ac.id/index.php/attadrib/article/view/160.

Nurjannah, Een, Engkus Kuswarno, Ahmad Mudrikah, and Usep Kosasih. "Teacher Performance Management in Improving Islamic Religious Education (IRE) Lesson Learning." Nidhomul Haq : Jurnal Manajemen Pendidikan Islam 6, no. 2 (August 1, 2021): 400-412. https://doi.org/10.31538/ndh.v6i2.1312.

Santosa, Sedya, and Aulia Diana Devi. "The Problematics Online Lectures on Human Resource Management Courses (HRM) at The Islamic College Level.” Nað̧runa: Jurnal Pendidikan Islam 4, no. 2 (June 20, 2021): 261-71. https://doi.org/10.31538/nzh.v4i2.1452.

Sulistyorini. Evaluasi Pendidikan Dalam Meningkatkan Mutu Pendidikan. Yogjakarta: Teras, 2009.

Suwadi, Suwadi. "Educational Leadership Based on Social Capital for Improving Quality of Private Secondary School." Jurnal Pendidikan Islam 6, no. 2 (December 27, 2017 ): 449. https://doi.org/10.14421/jpi.2017.62.449-478.

Wina, Sanjaya. Strategi Pembelajaran: Berorientasi Standar Psoses Pendidikan. 11th ed. Jakarta: Kencana Prenada Media Group, 2006. 